\title{
Two New Species of Edible Berries, One in Gaultheria L. and Other in Vaccinium L. (Ericaceae) from Costa Rica and Panama
}

\author{
Alexander Francisco Rojas-Alvarado*, Pablo Muñoz-Cambronero \\ Universidad Nacional de Costa Rica, Heredia, Costa Rica \\ Email: ^alfrojasa@yahoo.com
}

How to cite this paper: Rojas-Alvarado, A.F. and Muñoz-Cambronero, P. (2021) Two New Species of Edible Berries, One in Gaultheria L. and Other in Vaccinium L. (Ericaceae) from Costa Rica and Panama. Open Access Library Journal, 8: e8116.

https://doi.org/10.4236/oalib.1108116

Received: October 26, 2021

Accepted: November 27, 2021

Published: November 30, 2021*

Copyright $\odot 2021$ by author(s) and Open Access Library Inc.

This work is licensed under the Creative Commons Attribution International License (CC BY 4.0).

http://creativecommons.org/licenses/by/4.0/

\section{(c) (i) Open Access}

\begin{abstract}
Recent studies on the flora of paramos in Costa Rica, reveal two new endemic taxa described here as Gaultheria paramicola A. Rojas and Vaccinium reptans A. Rojas, both known only from Costa Rica and Panama. The first new species have been confused with Pernettya prostrata (Cav.) DC. (=Gaultheria myrsinoides Kunth), however due to its mucronate leaves without visible secondary veins and white to red fruits it is more related to G. mucronata (L. f.) Hook. \& Arn., a species only known from Chile and Argentina but differs because it is hermaphrodite (vs. monoecious), relative shorter plants, shorter laminar blade, shorter corolla, smaller fruits, higher altitudinal distribution and different geographical distribution. The second new species has been confused with Vaccinium consanguineum Klotzsch and $V$. floribundum Kunth but differs from both because it has procumbent (vs. erect) habit, ovate (vs. lanceolate) leaves, pruinose (vs. not or few pruinose), and insipid (vs. bittersweet) fruits with suberect (vs. appressed) calyx (except in V. floribundum).
\end{abstract}

\section{Subject Areas}

Plant Science

\section{Keywords}

Magnoliidae, Novelties, Paramos, Gaultheria mucronata(L. f.) Hook. \& Arn., Vaccinium consanguineum Klotzsch, Vaccinium floribundum Kunth

\section{Introduction}

Slaumer [1] in his revision of the genus Pernettya divides the genus into two sec- 
tions Archipernettya Sleumer and Pseudogaultheria Sleumer, the first comprises three series Pumilae Sleumer, Purpureae Sleumer and Mucronatae Sleumer, with $P$. prostrata and related species in the second series and $P$. mucronata in the third series.

Luteyn \& Wilbur [2], use the genus Pernettya different from Gaultheria because it has truly berry fruits, with basal calyx and not acrid (versus capsular fruits in Gaultheria but enveloped by the fleshy calyx). Middleton \& Wilcock [3], Powell \& Kron [4] and Teillier \& Escobar [5] include Pernettya as part of Gaultheria L., based on phylogenetic analysis.

The blueberry tribe (Vaccinieae) is a large and morphologically diverse group that is widespread in the temperate and tropical zones of most continents. The greatest species diversity is in the tropics, where Vaccinieae are a major component of montane cloud forests [6].

The synopsis of Vaccinium presented by Wilbur \& Luteyn [7] includes 27 species from Mexico and Central America, which gives some indication of the rich yield resulting from the more intensive fieldwork that has taken place within the region in the past seven decades. More than half of the Mexican and Central American species of Vaccinium have been described in the most recent three decades, while only four species (or about 15\%) were named in the first seventy-five years of the twentieth century and nine species (or $33 \%$ ) during the nineteenth century.

According to Kron et al. [6], Vaccinium consanguineum (Mesoamerican) forms a clade with $V$. floribundum (South American) and V. meridionale (Caribbean).

The purpose of this research is to describe two new species of berries discovered in the paramos of Costa Rica.

\section{Materials and Methods}

Recent studies in the vegetation of Costa Rican paramos made it possible to discover new taxa that will be published here and in other papers. The new species here considered are the result of comparisons with specimens of other neotropical species, and a review of related species and keys from the neotropical Ericaceae by Sleumer [1], Luteyn \& Wilbur [4], Wilbur \& Luteyn [7] and other papers that include Gaultheria (or Pennettya), Vaccinium and paramos vegetation as Teillier \& Escobar [4], Bischeimer [8], González [9], Idárraga, Ortiz, Callejas \& Merello [10], Luteyn [11], Vargas \& Sánchez [12], Weberling \& Furchheim [13]. The examined specimens are deposited in the CR, MO and USJ herbaria (acronyms following Thiers) [14]. To ensure the correct application names, original type material or digital type images were examined as available (Jstor Global Plants (http://plants.jstor.org/), and the new names were corroborated with International Plant Name Index

(http://www.ipni.org/ipni/plantnamesearchpage.do).

\section{Results}

Investigations in Costa Rican paramos made possible the discovering of two new 
edible of edible berries described here.

\subsection{New Taxa}

\subsubsection{Gaultheria paramicola A. Rojas, sp. nov.}

1) Type. COSTA RICA. San José: Dota, Copey, Cerro Las Vueltas, $9^{\circ} 37^{\prime} 40^{\prime \prime} \mathrm{N}$, 8351'10"W, 3160 m, 3 Sept 2016, A. Rojas \& P. Muñoz 10034 (Holotype: CR, Isotypes: $\mathrm{K}, \mathrm{MO}$, USJ).

2) Diagnoses. Gaultheria paramicola A. Rojas differs from Gaultheria mucronata (L. f.) Hook. \& Arn. by hermaphrodite (vs. monecious) and relative smaller (10 - $40(-60) \mathrm{cm}$ tall vs. (20-) $40-250 \mathrm{~cm}$ tall) plants, smaller $(0.4-1.2 \times$ $0.25-0.6 \mathrm{~cm}$ vs. $1-2 \times 0.4-0.6(-1) \mathrm{cm}$ ) blades, shorter $(2-3.5 \mathrm{~mm}$ long vs. 5 $6 \mathrm{~mm}$ long) corolla, shorter (3 - $6 \mathrm{~mm}$ broad $\times 4-6(-7) \mathrm{mm}$ long vs. $6-8(-10)$ $\mathrm{mm}$ in diameter) fruits, and different altitudinal [(2400-) $3000-3800 \mathrm{~m}$ vs. 0 $1050(-2200 \mathrm{~m})$ and geographical (Costa Rica and Panama vs. Bolivia, Argentina and Chile) distribution(see Figures 1-3, Table 1).

3) Description. Epilithic or terrestrial shrubs 10 - $40(-60) \mathrm{cm}$ tall, few branched, commonly stoloniferous. Branchlets few, terete, glabrous. Leaves $0.5-1.3 \mathrm{~cm}$ long, coriaceous, persistent; petiole $0.5-1.5 \mathrm{~mm}$ long; blades $0.4-1.2 \times 0.25-0.6 \mathrm{~cm}$,

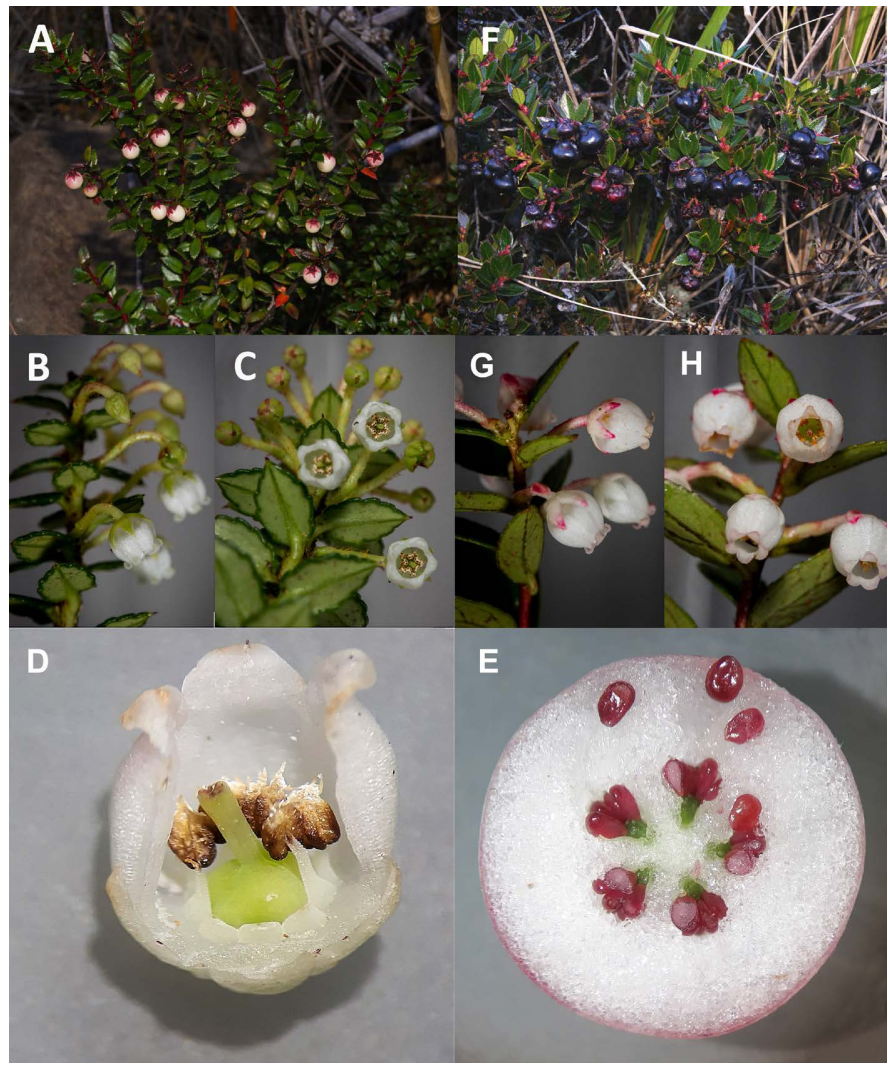

Figure 1. Gaultheria paramicola A. Rojas. (A) Habit; (B) Flowers seen laterally; (C) Front view flowers; (D) Longitudinal section of flower showing stamens and pistil; (E) Cross section of fruit showing locules and seeds. G. myrsinoides Kunth; (F) Habit; (G) Flowers seen laterally; (H) Front view flowers. Photographs (A) and (F) taken by Armando Estrada Chavarría. 


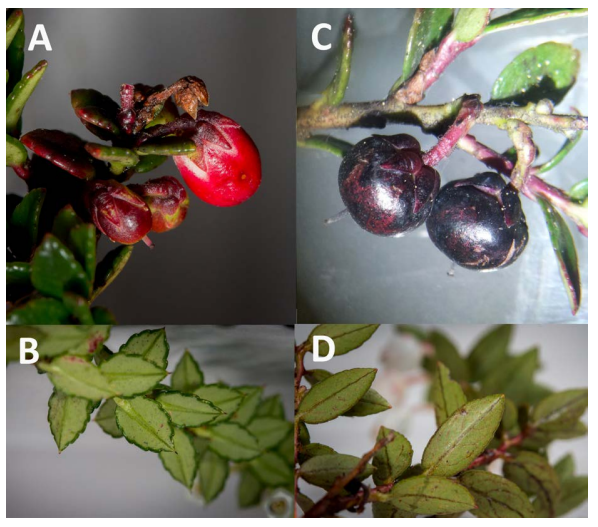

Figure 2. Gaultheria paramicola A. Rojas. (A) Branch with fruits; (B) Leaves seen abaxially. G. myrsinoides Kunth; (C) Branch with fruits; (D) Leaves seen abaxially.

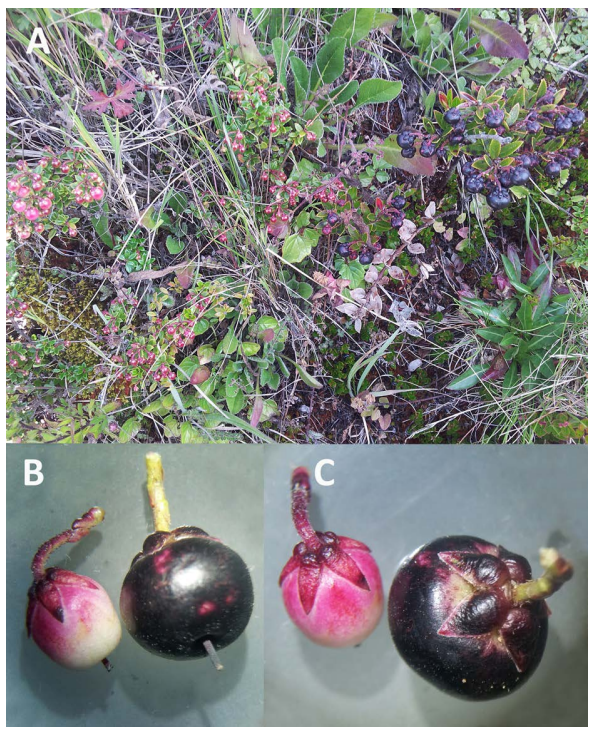

Figure 3. (A) Mixed living plants of Gaultheria paramicola A. Rojas (at left) and G. myrsinoides Kunth. (at right). (B) (C) Comparative fruits of $G$. paramicola (at left) and G. myrsinoides (at right) [(B) lateral view and (C) top view of both taxa (G. paramicola at left and G. myrsinoides at right]. Photograph (A) taken by Armando Estrada Chavarría.

ovate to broadly elliptic, with 4 - 5 incisions to each side of blade, dark green adaxially, pale green abaxially, glabrous in both surfaces, central vein prominent throughout its length ending in a mucron of $0.1-1 \mathrm{~mm}$, secondary veins not visible. Flowers individual and grouped at apex of branches, $0.7-1.0 \mathrm{~cm}$ long; pedicels 4 - $7 \mathrm{~mm}$ long, hairy; calyx deeply split, lobes $1.5-2.5 \mathrm{~mm}$ long, yellow-green in flowers to red in fruits, glabrous, deltoid, acute at apex; corolla 2.0 $3.5 \mathrm{~mm}$ long, $2.0-3.5 \mathrm{~mm}$ in diameter, urceolate, globose, gamopetaly, with apex as wide as the base, white, glabrous, the lobes recurved or revolute, deltoid, acute, ca. 1.0 - $1.5 \mathrm{~mm}$ long, glabrous; stamens 10, 1.5 - $3 \mathrm{~mm}$ long, included in two series, the internal series (five stamens) longer than the others five; filaments 
Table 1. Comparison of morphological characteristics among three taxa of Gaultheria: G. mucronata (L. f.) Hook. \& Arn., G. paramicola A. Rojas and G. myrsinoides Kunth.

\begin{tabular}{|c|c|c|c|}
\hline Character & G. mucronata & G. paramicola & G. myrsinoides \\
\hline Sexuality & monoecious & hermaphrodite & hermaphrodite \\
\hline Plans tall & $(20-) 40-250 \mathrm{~cm}$ & $10-40(-60) \mathrm{cm}$ & $10-400 \mathrm{~cm}$ \\
\hline Blade size & $1-2 \times 0.4-0.6(-1) \mathrm{cm}$ & $0.4-1.2 \times 0.25-0.6 \mathrm{~cm}$ & $\begin{array}{c}(0.8-) 1.2-2(-4) \times 0.4-0.9(-1.2) \\
\mathrm{cm}\end{array}$ \\
\hline Blade apex & mucronate & mucronate & obtuse to acute \\
\hline Blade margin & $\begin{array}{c}\text { with } 4 \text { - } 5 \text { incisions to each side of } \\
\text { blade }\end{array}$ & $\begin{array}{l}\text { mucronate with } 4 \text { - } 5 \text { incisions to } \\
\text { each side of blade }\end{array}$ & $\begin{array}{c}\text { with } 6-9(-11) \text { incisions to each } \\
\text { side of blade }\end{array}$ \\
\hline main vein abaxially & highlighted throughout its length & highlighted throughout its length & highlighted only at base \\
\hline Secondary veins & not evident & not evident & Conspicuous \\
\hline Corolla size & $5-6 \mathrm{~mm}$ long & $2-3.5 \mathrm{~mm}$ long & $5-6(-7) \mathrm{mm}$ \\
\hline Corolla form & Urceolate to urceolate-cylindrical & urceolate & urceolate-cylindrical \\
\hline Corolla apex & as wide as the base to narrower & as wide as the base & narrower than the base \\
\hline Corolla color & white & white & white to pink \\
\hline Fruits size & $6-8(-10) \mathrm{mm}$ in diameter & $\begin{array}{c}3-6 \mathrm{~mm} \text { broad } \times 4-6(-7) \mathrm{mm} \\
\text { long }\end{array}$ & $6-1.6 \mathrm{~mm}$ in diameter \\
\hline Fruits form & globose, contracted at apex & $\begin{array}{l}\text { globose to elongated, rounded at } \\
\text { apex }\end{array}$ & globose, contracted at apex \\
\hline Fruits color & white to red & white to red & black \\
\hline $\begin{array}{c}\text { Altitudinal } \\
\text { distribution } \\
\text { Geographical } \\
\text { distribution }\end{array}$ & $\begin{array}{c}0-1050(-2200) \mathrm{m} \\
\text { Bolivia, Argentina and Chile }\end{array}$ & $\begin{array}{c}(2400-) 3000-3800 \mathrm{~m} \\
\text { Costa Rica and Panama }\end{array}$ & $\begin{array}{l}\text { (900-) } 2000 \text { - } 3900(-4630) \mathrm{m} \\
\text { México, Guatemala, Honduras, } \\
\text { Nicaragua, Costa Rica, Panama, } \\
\text { Colombia, Venezuela, Ecuador, } \\
\text { Peru, Bolivia and Argentina }\end{array}$ \\
\hline
\end{tabular}

$1-2 \mathrm{~mm}$ long, white, puberulent; anthers ca. $1 \mathrm{~mm}$ long, brown with white patches, ciliate. Fruits $3-6 \mathrm{~mm}$ broad $\times 4-6(-7) \mathrm{mm}$ long, fleshy, globose to elongate with rounded apex and white to red color, $4-5$ locular but without aerial space.

4) Etymology. The name of this variety makes references to its habitat in paramos (with shrub or herbaceous vegetation typical of the mountains peaks in Central and South America at more than 3000 meters high).

5) Distribution. Known only from Costa Rica and Panama at (2400-) 3000 $3800 \mathrm{~m}$ elevation in paramo vegetation.

6) Additional revised specimens. COSTA RICA. Cartago: El Guarco, Reventazón Basin, La Chonta, $3 \mathrm{~km} \mathrm{~S}$ del Empalme, at right hand of Interamericana Sur, $9^{\circ} 42^{\prime} 33^{\prime \prime} \mathrm{N}, 83^{\circ} 56^{\prime} 51^{\prime \prime} \mathrm{W}, 2400 \mathrm{~m}, 4$ July 2000, B. Brak \& M. Vroklage 58 (CR, MO); about $5 \mathrm{~km}$ E of the highest point on the Interamerican Hwy. (W of Villa Mills), 9³3'N, 834' W, 3200 m, 13 Jan 1967, W. Burger \& G. Matta 4367 (CR); summit of Cerro Sábila, near km 86, Rute 2, 3420 m, 25 May 1983, $A$. Chaverri 1326 (CR); Cordillera de Talamanca, Cerro de La Muerte, Interameri- 
can Hwy, Rute 2, km 89, ca. 3000 m, 5 Aug 1987, G. Crow 6992 (CR); ibídem, $9^{\circ} 04^{\prime} \mathrm{N}, 83^{\circ} 45^{\prime} \mathrm{W}, 3150$ m, 19 Oct 1989, G. Crow \& D. Rivera 7398 (CR); Cerro de La Muerte, Pan-American Highway, $5 \mathrm{~km}$ above Millsville (about $8 \mathrm{~km}$ above Nivel), Cordillera de Talamanca, 3400 - 3500 m, July 1949, R. Holm \& H. Iltis 585 (CR); “Cerro de La Muerte” región, Cordillera de Talamanca, lower S face of Cerro Zacatales, 3340 m, 4 Jan 1985, S. Horn 26 (CR); peak of Cerro Asunción, South Panamerican Hwy., 3396 m, 25 Feb 1965, A. Jiménez 2968 (CR); Cerro de La Muerte, 3400 m, J. Reark 448 (CR); Cerro Asunción, leeward side of moun-

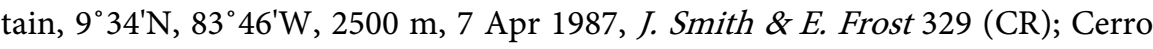
de La Muerte, Cordillera de Talamanca, 3100 m, 6 Feb 1963, L. Williams et al. 24474 (CR). Cartago/San José: Cartago-San José province border, Cordillera de Talamanca, Interamerican Hwy. about midway between Cerro Asunción and Cerro Zacatales, 10300 ft [3140 m], 10 Mar 1981, F. Almeda \& K. Nakai 4837 (CR). Limón: Talamanca, La Amistad International Park, Sixaola basin, Cerro Kámuk, 9¹6'15"N, 8302'05"W, 3400 m, 22 July 2000, E. Alfaro 3304 (CR, MO); Chirripó National Park, between Casa de Administración and peak, 3400 m, 13 Feb 1983, N. Garwood et al. 1196 (CR); San José: Cantón de Pérez Zeledón, Chirripó National Park, Térraba-Sierpe basin, Crestones Base, 9 $27^{\prime} 25^{\prime \prime} \mathrm{N}$, $83^{\circ} 30^{\prime} 38^{\prime \prime W}, 3460 \mathrm{~m}, 7 \mathrm{Dec} 1996$, E. Alfaro 1004 (CR, MO); in the vicinity of the communication towers, 3370 m, 23 Feb 1991, F. Almeda et al. 6800 (CR); Cerro de La Muerte (C. Buenavista), 9³3'N, 8346'W, 3300 - 3400 m, 21 Aug 1982, W. Alverson 1844 (CR, WIS); ibídem, W. Alverson 1873 (CR, WIS); vicinity of Cerro Buena Vista (Cerro de La Muerte range), 1 - $2 \mathrm{~km} \mathrm{~S}$ of Pan-American Hwy., 9³4'N, 83ํ5'W, 3300 m, 12 July 1994, W. Alverson \& D. Price 2654 (CR); Valle de Los Conejos, (upper Rio Talari) and trails Cerro Chirripó and the Valle de Los Lagos, 9 ${ }^{\circ} 30^{\prime} \mathrm{N}, 83^{\circ} 31^{\prime} \mathrm{W}, 3400$ - 3820 m, 19 - 22 Jan 1970, W. Burger \& R. Liesner 7479 (CR, MO); Macizo Buenavista, 3400 m, 22 June 1983, A. Chaverri \& V. López 1546 (CR); Cerro Buenavista, Macizo Buenavista, 3450 m, 1 July 1983, A. Chaverri \& V. López 1363 (CR); N and W slopes of Cerro Páramo, Buenavista massif (Cerro de La Muerte), Cordillera de Talamanca, $9^{\circ} 33.5^{\prime} \mathrm{N}$, 8345.5'W, 3400 - 3485 m, 12 Mar 1987, M. Grayum \& J. Affolter 8180 (CR, MO); Chirripó National Park, Cordillera de Talamanca, S facing slope of Valle de Los Conejos, about 1 km S of Cerro Nuevo, 3475 m, 18 Feb 1985, S. Horn 50 (CR); N slopes of Cerro Buenavista, to $\mathrm{S}$ of Interamerican Hwy. crossing Cerro de La Muerte, 9³4'08"N, 8345'09"W, 3250 - 3450 m, 12 July 1994, W. Kress \& C. Christy 94 - 5120 (CR); ibídem, W. Kress \& L. Cablk 94 - 5166 (CR); Cordillera de Talamanca, Buena Vista Massif, Cerro Páramo, occidental slope, ca. $15 \mathrm{~m}$ down the peak, ca. 3460 m, 9 Mar 1971, H. Kuhbier 293 (CR); Cantón de Pérez Zeledón, Dota, San Gerardo, top of Cerro de La Muerte near radio towers, $9^{\circ} 32^{\prime} 55^{\prime \prime} \mathrm{N}, 83^{\circ} 48^{\prime} 10^{\prime \prime} \mathrm{W}, 3275$ m, 20 June 2004, R. Moran et al. 7329 (CR); Cantón de Dota, Cordillera de Talamanca, Cañón, Los Chespiritos 2 restaurant, joined to Interamerican Hwy., 941'10"N, 8355'00"W, 2500 m, 13 Aug 1993, V. Ramírez et al. 36 (CR, MO); Pérez Zeledón, Los Santos Forestal Reserve, Savegre basin, 
Cerro Buenavista, Las Torres, 9³3'20"N, 8345'30"W, 3000 m, 11 abr 1996, $A$. Rodríguez \& A. Estrada 1093 (CR, MO); Pérez Zeledón, Los Santos Forestal Reserve, Savegre basin, Cerro Buenavista, Las Torres, 9³3'20"N, 8345'30"W, 3400 m, 6 Sep 1996, A. Rodríguez et al. 1482 (CR, MO); Dota, Copey, Cerro Vueltas Biological Reserve, 9³7’30"N, 8505’10"W, 3100 m, 17 July 1997, J. Sánchez \& A. Estrada 854 (CR); Cerro Buena Vista, trail to Interamerican Hwy., toward radio towers, 29 Dec 1988, J. Schneider 98 (CR); trail to Cerro Chirripó, ca. 3700 m, 19 Apr 1989, J. Schneder \& G. Schneider 229 (CR); Chirripó National Park, down Cerro Chirripó, 3750 m, 3 Nov 1988, J. Schneider \& G. Vargas 68 (CR); 3700 - 3800 m, J. Schneider \& G. Vargas 73 (CR); Chirripó Massif, around lagoon contiguous to Lago Mayor, 5 Mar 1957, H. Weber \& A. Jiménez 1823 (CR); ibídem, H. Weber \& A. Jiménez 1827 (CR); Cerro Buenavista, Buenavista Massif, ca. 3400 m, 28 Aug 1969, A. Weston 5971 (CR, MO); ibídem, 27 Mar 1971, A. Weston 6252 (CR). PANAMA. Chiriquí: Ridge above Alto Pineda, 08 $49^{\prime} \mathrm{N}$, $82^{\circ} 32^{\prime} \mathrm{W}, 9000-10400 \mathrm{ft}$ [2745 - $3170 \mathrm{~m}$ ], 15 Apr 1979, B. Hammel et al. 7103 (MO).

7) Comparative analysis. The new species is different from Gaultheria mucronata by the characters mentioned in the diagnoses. Also is different from $G$. myrsinoides because has smaller $(10-40(-60) \mathrm{cm}$ tall vs. $10-400 \mathrm{~cm}$ tall $)$ plants, smaller $(0.4-1.2 \times 0.25-0.6 \mathrm{~cm}$ vs. $(0.8-) 1.2-2(-4) \times 0.4-0.9(-1.2)$ $\mathrm{cm}$ ) blades with mucronate (vs. obtuse to acute) apex, with 4 - 5 incisions (vs. 6 $9(-11)$ incisions) to each side of blade, highlighted throughout its length (vs. highlighted only at base), main vein abaxially and not evident (vs. conspicuous) secondary veins, shorter (2 - $3.5 \mathrm{~mm}$ long vs. 5 - $6(-7) \mathrm{mm}$ long) corolla and with white (vs. pink) color, shorter $(3-6 \mathrm{~mm}$ broad $\times 4-6(-7) \mathrm{mm}$ long vs. $6-$ $8(-10) \mathrm{mm}$ in diameter) fruits with white to red (vs. black) color and they edible (vs. poisonous) (see Figures 1-3, Table 1).

\subsubsection{Vaccinium reptans A. Rojas, sp. nov.}

1) Type. COSTA RICA. San José: Dota, Copey, Cerro Las Vueltas, $9^{\circ} 37^{\prime} 40^{\prime \prime N}$, 8351'10"W, 3160 m, 3 Sept 2016, A. Rojas \& P. Muñoz 10035 (Holotype: CR; Isotypes: $\mathrm{K}, \mathrm{MO}$, USJ).

2) Diagnoses. Vaccinium reptans A. Rojas differs from Vaccinium consanguineum Klotzsch because has suffrutescent or decumbent (vs. erect) habit, 0.1 $0.4(-0.6) \mathrm{m}$ (vs. (0.3-) 1 - $10(-15) \mathrm{m}$ ) plant tall, arched to horizontal (vs. vertical or ascending) branches, ovate to broadly elliptic (vs. narrow to broadly elliptic or oblong) blades and they $0.6-1.3 \times 0.3-0.8 \mathrm{~cm}$ (vs. (1-) $1.5-3(-5.8) \times 0.5-1.2$ $(-2.2) \mathrm{cm}$ ) with broadly cuneate to rounded (vs. acute to cuneate) base and broadly cuneate to rounded (vs. acute to obtuse) apex, elongate at base and globose at apex (vs. cylindrical) corolla and it 3 - $5 \mathrm{~mm}$ long (vs. 5 - $7.5 \mathrm{~mm}$ long) with pink (sometimes with red patches) (vs. white) color, black (vs. reddish to black) fruits with pruinose (vs. not or few pruinose) surface, insipid (vs. bittersweet) flavor, with suberect (vs. appressed) calyx and persistent (vs. deciduous) flower style (see Figure 4 and Figure 5, Table 2). 


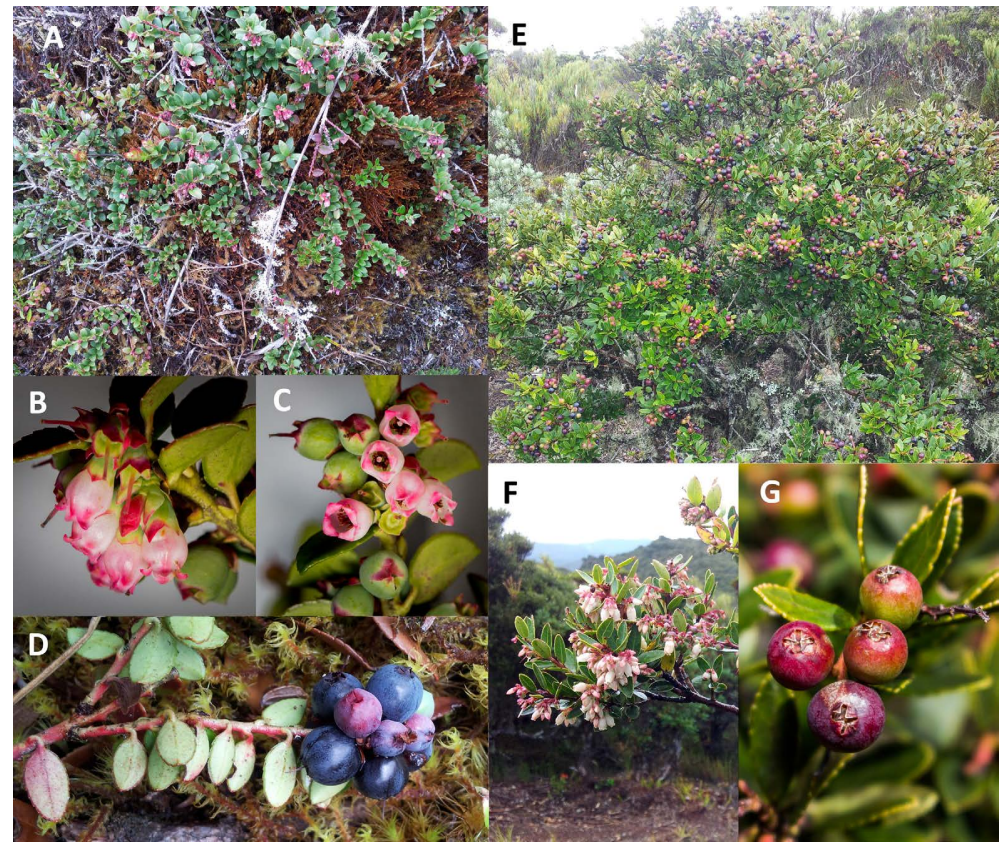

Figure 4. Vaccinium reptans A. Rojas. (A) Upper view of habit; (B) Branch with flowers in lateral view; (C) Branch with flowers in down view; (D) Branch with mature fruits. $V$. consanguineum Klotzsch; (E) Lateral view of habit; (F) Branch with flowers; $(\mathrm{G})$ Branch with mature fruits.

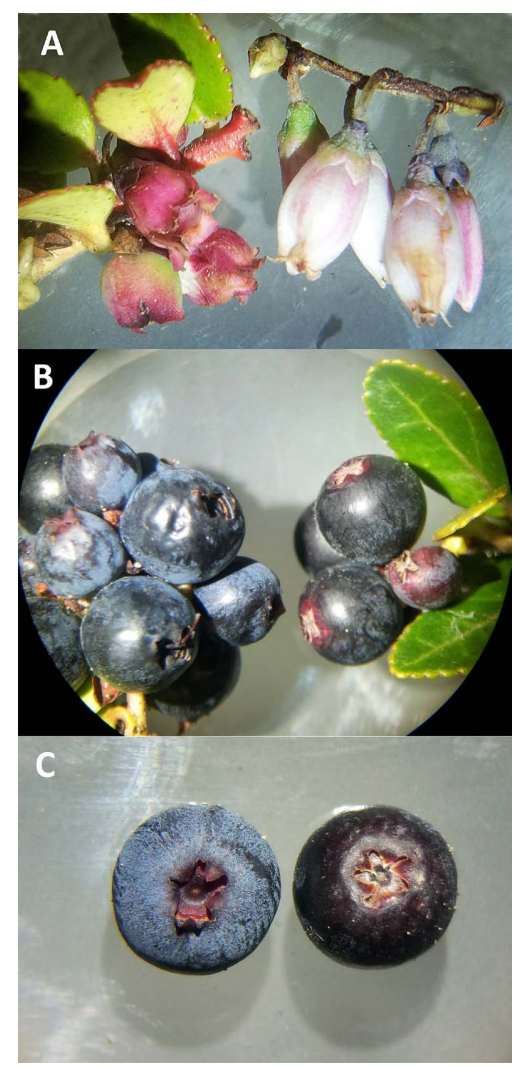

Figure 5. Comparative structures between Vaccinium reptans A. Rojas (at left in all pictures) and $V$. consanguineum Klotzsch (at right in all pictures). (A) Leaves; (B) Flowers. (C) and D. Fruits. 
Table 2. Comparison of morphological characteristics among three species of Vaccinium: $V$. consanguineum Klotzsch, $V$. floribundum Kunth and V. reptans A. Rojas.

\begin{tabular}{|c|c|c|c|}
\hline Character & V. consanguineum & V. floribundum & $V$. reptans \\
\hline Plans tall & $(0.3-) 1-10(-15) \mathrm{m}$ & $0.2-1.2(-2.5) \mathrm{m}$ & $0.1-0.4(-0.6) \mathrm{m}$ \\
\hline Branches & vertical or ascending & ascending & arched to horizontal \\
\hline Blade size & 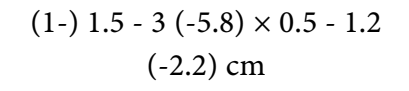 & $0.4-1.5(-2.5) \times 0.3-1.2 \mathrm{~cm}$ & $0.6-1.3 \times 0.3-0.8 \mathrm{~cm}$ \\
\hline Blade form & $\begin{array}{l}\text { narrow to broadly elliptic } \\
\text { or oblong }\end{array}$ & elliptic to ovate-lanceolate & ovate to broadly elliptic \\
\hline Blade base & acute to cuneate & acute to cuneate & broadly cuneate to rounded \\
\hline Blade apex & acute to obtuse & acute to obtuse & obtuse to rounded \\
\hline Corolla size & $5-7.5 \mathrm{~mm}$ long & $5-6.5 \mathrm{~mm}$ long & 3 - $5 \mathrm{~mm}$ long \\
\hline Corolla form & cylindrical & cylindrical & $\begin{array}{l}\text { urceolate, elongate at base and } \\
\text { globose at apex }\end{array}$ \\
\hline Corolla color & white & white to pink & pink (sometime with red patches) \\
\hline Fruits color & reddish to black & black & black \\
\hline Fruits surface & not pruinose or few & pruinose or not & strongly pruinose \\
\hline Remanent calyx in fruits & appressed & suberect & suberect \\
\hline $\begin{array}{l}\text { flower style persistent } \\
\text { in fruit }\end{array}$ & no & commonly & commonly \\
\hline fruit flavor & bittersweet & bittersweet & insipid \\
\hline $\begin{array}{l}\text { Geographical } \\
\text { distribution }\end{array}$ & $\begin{array}{c}\text { Mexico, Honduras, Costa Rica } \\
\text { and Panama }\end{array}$ & $\begin{array}{c}\text { Colombia, Venezuela, Ecuador, } \\
\text { Peru, Bolivia and Argentina }\end{array}$ & Costa Rica and Panama \\
\hline
\end{tabular}

3) Description. Terrestrial or epilithic herb or shrub, suffrutescent or procumbent, $0.1-0.4(-0.6) \mathrm{m}$ tall. Leaves $0.7-1.5 \mathrm{~cm}$ long, $0.2-0.5(-1) \mathrm{cm}$ distant between the same side leaves, alternate; petiole $0.05-0.2 \mathrm{~cm}$ long, flattened in the adaxial surface, glabrous to shortly hairy; blades $0.6-1.3 \times 0.3-0.8 \mathrm{~cm}$, ovate to broadly elliptic, coriaceous, broadly cuneate to rounded at base, obtuse to rounded at apex, crenate-serrated at margin, dark green adaxially, pale green abaxially, glabrous to sparsely hairy in both surfaces, pinnately nerved. Inflorescences racemose with 6 - 10 flowers; flowers with pedicel 7 - $10 \mathrm{~mm}$ long; floral bracts 2, $1-2 \mathrm{~mm}$ long; calyx $1-1.5 \mathrm{~mm}$ long, with $4-5$ lobes, broadly deltate, glabrous; corolla 3 - $5 \mathrm{~mm}$ long, urceolate, elongate at base and globose at apex, glabrous, pink (sometimes with red patches), with 4 - 5 lobes, they erect to recurved, deltoid, acute; stamens 8 or 10, 2 - $4 \mathrm{~mm}$ long; filaments $1.5-2.5 \mathrm{~mm}$ long. Fruits 5 - $8 \mathrm{~mm}$ in diameter, globose, black, strongly pruinose or glaucous, glabrous, with suberect remanent calyx and persistent style flower, 4 - 5 locular but with aerial space in each one.

4) Etymology. The name of its species makes references to decumbent habit.

5) Distribution. Known only from Costa Rica and Panama at (3000-) 3160 $3750 \mathrm{~m}$ elevation in paramo vegetation.

6) Additional revised specimens. COSTA RICA. Cartago: "Cerro de La 
Muerte" region, Cordillera de Talamanca, Cerro Sákira, $80 \mathrm{~m}$ N of summit, 3400 m, 28 Mar 1985, S. Horn 131 (CR); Cerro Sákira, Buenavista massif, 9³5'35"N, 8345'38"W, 3417 m, 5 June 1993, G. Vargas et al. 1421 (CR); Buenavista massif, Sákira summit, 3417 m, 29 Aug 1969, A. Weston 6005 (CR, F). Limón: Cordillera de Talamanca, Atlantic slope, Kámuk massif, NE of the main Kámuk peak, $9^{\circ} 16-17^{\prime} \mathrm{N}, 83^{\circ} 00$ - 02'W, 3000 - 3300 m, 17 - 18 Sep 1984, G. Davidse \& G. Herrera 29302 (CR, MO); Cordillera de Talamanca, SW foot of Cerro Kámuk, $9^{\circ} 16^{\prime} \mathrm{N}, 83^{\circ} 02^{\prime} 30^{\prime \prime} \mathrm{W}, 3200$ - $3350 \mathrm{~m}, 24$ Mar 1984, G. Davidse et al. 25979 (CR, MO). San José: Dota, Copey, Cerro Las Vueltas, 9³7'40"N, 8351'10"W, 3160 m, 18 Jul 1997, A. Estrada \& J. Sánchez 1034 (CR); Chirripó National Park, trail to Cerro Chirripó, $100 \mathrm{~m}$ of the trail to Valle de Las Morenas, ca. $3750 \mathrm{~m}, 19$ Apr 1989, J. Schneider \& G. Schneider 230 (CR); Sabana de Los Leones, Chirripó National Park, 20 Apr 1989, J. Schneider \& G. Schneider 239 (CR); Pérez Zeledón, Reserva Forestal Los Santos, Savegre basin, Cerro Buenavista, around the radio towers, 9 $33^{\prime} 20^{\prime \prime} \mathrm{N}, 83^{\circ} 45^{\prime} 30^{\prime \prime} \mathrm{W}, 3400 \mathrm{~m}, 24$ Abr 1998, L. Vargas et al. 59 (CR, $\mathrm{MO})$.

PANAMA. Bocas del Toro: Cerro Fábrega and ridge to North, $14 \mathrm{~km} \mathrm{NE}$ (straight line) of Estación Pittier, 9 $06^{\prime} 52^{\prime \prime N}, 82^{\circ} 52^{\prime} 26^{\prime \prime} \mathrm{W}, 3300$ m, 3 Mar 2006, $A$. Monro \& S. Knapp 5151 (BM, MO, PMA); S between Cerro Itamut and 'El Pyramide', 9 $05^{\prime} 46^{\prime \prime}$, 82 $52^{\prime} 25^{\prime \prime} \mathrm{W}, 3200$ m, 11 Mar 2006, A. Monro \& S. Knapp 5296 (BM, MO, PMA); Cordillera de Talamanca, Cerro Echandi, on the international border, La Amistad International Park, 9 $02^{\prime} \mathrm{N}, 82^{\circ} 49^{\prime} \mathrm{W}, 3050-3160 \mathrm{~m}$, 22 Aug 1983, G. Davidse et al. 23856 (MO).

7) Comparative analysis. The new species is different from Vaccinium consanguineum Klotzsch by the characters mentioned in the diagnoses. Also is different from $V$. floribundumKunth because has suffrutescent or decumbent (vs. erect) habit, $0.1-0.4(-0.6) \mathrm{m}$ (vs. 0.2 - $1.2(-2.5) \mathrm{m}$ ) plant tall, arched to horizontal (vs. vertical or ascending) branches, ovate to broadly elliptic (vs. elliptic to ovate-lanceolate) blades with broadly cuneate to rounded (vs. acute to cuneate) base and broadly cuneate to rounded (vs. acute to obtuse) apex, elongate at base and globose at apex (vs. cylindrical) corolla and it $3-5 \mathrm{~mm}$ long (vs. $5-6.5 \mathrm{~mm}$ long) with pruinose (vs. not or few pruinose) surface and insipid (vs. bittersweet) flavor (see Figure 4 and Figure 5, Table 2).

\section{Discussion}

Weberling and Furchheim [13] mentioned to Pernettya prostrata (= Gaultheria myrsinoides) with size of plants between 10 and $30 \mathrm{~cm}$ tall and red fruits with a light apple flavor, however that characters correspond with G.paramicola here described. The same authors made referenced to $P$. coriacea with a size of $0.1-2$ $\mathrm{m}$ tall and bluish and farinose fruits thar correspont with Gaultheria myrsinoides a species mentioned by Rincón et al. [15] with the presence of poisonous fruits.

Luteyn [16] reports that in the paramos of Costa Rica that P. prostrata have 
populations with the apex of the leaves shortly mucronized and apparently with red berries (when ripe). These populations may represent a different species, but further study is required to determine this. Undoubtedly the taxa mentioned is the same described here as $G$. paramicola.

Weberling and Furchheim [13] mentioned to Vaccinium floribundum growing horizontally on rocky ground and with aerial shoots that barely exceed 10 to $15 \mathrm{~cm}$ above the ground, two characters typical of $V$. reptans here described. Also Luteyn \& Wilbur [2] inform to $V$. floribundum with sufrutescent herb procumbent to a suberect shrub, character same as the new species described here. However, the type specimens (Peru, Amazonas, Cajamarca, Humboldt \& Bonpland s.n. (holotype: P-Bonpl.!; Isotype: P!) shows erect and long branches with lanceolate blades (narrower than the new taxa and with acute apex), an entity that has white flowers with elongate corolla. Additionally, in Colombia and Ecuador several pictures have been uploaded to the internet with pink and broad corolla, but inclusive they have erected and long branches. After that, more studies are needed to resolve this complex group.

In different papers and books Vaccinium floribundum is mentioned from Costa Rica, but probably this species is restricted from South America; however, in Costa Rica two entities of tree or bush are present, one with globose tree top present in paramos or open areas between $2800-3550 \mathrm{~m}$ and it with close hypanthium which correspond with $V$. consanguineum and the other one with irregular tree top present in montane forest between (1600-) $2000-3100 \mathrm{~m}$ and it with open hypanthium at apex which probably correspond with $V$. meridionale Sw.

\section{Conclusion}

The main contribution of this research is the discovery of two new species for science of the Ericaceae family, which belong to the group of blueberries, they are edible for humans and probably same as other blueberries with high content of antioxidant chemical compounds. Use of fruits with antioxidant content in Ericaceae family [17], or other medical plants [18] joined with probiotics organisms [19] could be a great solution in food industry.

\section{Acknowledgments}

This work was possible thanks to Universidad Nacional de Costa Rica (UNA) and Sistema Nacional de Áreas de Conservación (SINAC). Thanks also to Herbario Nacional de Costa Rica (CR) for providing specimen loans and the space for analyze the specimens. Thanks to Armando Estrada for the photographs, to the anonymous reviewers for their help; and to all who, in one way or another, made this work possible.

\section{Conflicts of Interest}

The authors declare no conflicts of interest. 


\section{References}

[1] Sleumer, H. (1935) Revision der Gattung Pernettya Gaud. Notizblatt des Königl. botanischen Gartens und Museums zu Berlin, 12, 626-655.

http://www.jstor.org/stable/3994858

https://doi.org/10.2307/3994858

[2] Luteyn, J.L. and Wilbur, R.L. (2010) Ericaceae. In: Hammel, B., Grayum, M.H., Herrera, C. and Zamora, N., Eds., Eds., Manual de Plantas de Costa Rica, Vol. 5, Missouri Botanical Garden, St. Louis, 239-283.

[3] Middleton, D.J. and Wilcock, C.C. (1990) A Critical Examination of the Status of Pernettya as a Genus Distinct from Gaultheria. Edinburgh Journal of Botany, 47, 291-301. https://doi.org/10.1017/S0960428600003449

[4] Powell, E.A. and Kron, K.A. (2001) An Analysis of the Phylogenetic Relationships in the Wintergreen Group (Diplycosia, Gaultheria, Pernettya, Tepuia; Ericaceae). Systematic Botany, 26, 808-817. http://www.bioone.org/doi/full/10.1043/0363-6445-26.4.808

[5] Teillier, S. and Escobar, F. (2013) Revisión del género Gaultheria L. (Ericaceae) en Chile. Gayana Botánica, 70, 136-153. https://doi.org/10.4067/S0717-66432013000100014

[6] Kron, K.A., Powell, E.A. and Luteyn, J.L. (2002) Phylogenetic Relationships within the Blueberry tribe (Vaccinieae, Ericaceae) Based on Sequence Data from MATK and Nuclear Ribosomal Its Regions, with Ribosomal Its Region, with Comments on the Placement of Satyria. American Journal of Botany, 89, 327-336. https://doi.org/10.3732/ajb.89.2.327

[7] Wilbur, R.L. and Luteyn, J.L. (2008) A Synopsis of the Mexican and Central American Species of Vaccinium (Ericaceae). Journal of the Botanical Research Institute of Texas, 2, 207-241. http://www.jstor.org/stable/41971620

[8] Bischeimer, M.V. (2012) Flores de la Patagonia Argentina. Flores nativas y exóticas presentes en los ambientes cordilleranos y precordilleranos de la Patagonia Argentina, $1^{\text {a }}$. Ed., Serie Patagonia, Neuquén, 240 p.

[9] González, L. (2005) Árboles y arbustos comunes del Parque Internacional La Amistad. National Biodiversity Institute, Santo Domingo, 286 p.

[10] Idárraga-Piedrahita, A., Ortiz, D.C., Callejas, R. and Merello, M. (Eds.) (2011) Flora de Antioquia: Catálogo, 2, 9-939. Universidad de Antioquia, Medellín.

[11] Luteyn, J.L. (1999) Paramos, a Checklist of Plant Diversity, Geographical Distribution, and Botanical Literature. Memoirs of the New York Botanical Garden, 84, 1-278.

[12] Vargas, G. and Sánchez, J.J. (2005) Plantas con flores de los páramos de Costa Rica y Panamá: El páramo Ístmico. In: Kappelle, M. and Horn, S.P., Eds., Páramos de Costa Rica, National Biodiversity Institute, Santo Domingo, 397-435.

[13] Weberling, F. and Furchheim, B. (2005) El mosaico de formas de crecimiento en los páramos de Costa Rica. In: Kappelle, M. and Horn, S., Eds., Páramos de Costa Rica, National Biodiversity Institute, Santo Domingo, 437-476.

[14] Thiers, B. (2016) Index Herbariorum: A Global Directory of Public Herbaria and Associated Staff. New York Botanical Garden's Virtual Herbarium. [Continuously Updated]. http://sweetgum.nybg.org/science/ih/

[15] Rincón, C.M, Patiño, O.J., Plazas, E.A., Bulla, M.E., Rozo G. and Puyana, M. (2014) Estudio químico preliminar y evaluación de la actividad antioxidante, antialimentaria y tóxica, de la especie Pernettya prostrata (Ericaceae). Revista Cubana de Plantas Medicinales, 19, 138-150. 
[16] Luteyn, J.L. (2015) Pernettya prostrata. (Cav.) DC. Flora Mesoamericana. http://legacy.tropicos.org/Name/50066293?projectid=3\&langid=66

[17] Huang, W.Y., Zhang, H.C., Liu, W.X. and Li, C.Y. (2012) Survey of Antioxidant Capacity and Phenolic Composition of Blueberry, Blackberry, and Strawberry in Nanjing. Journal of Zhejiang University-SCIENCE B (Biomedicine \& Biotechnology), 13, 94-102. https://doi.org/10.1631/jzus.B1100137

[18] Berlowski, A., Zawada, K., Wawer, I. and Paradowska, K. (2013) Antioxidant Properties of Medicinal Plants from Peru. Food and Nutrition Sciences, 4, 71-77. https://doi.org/10.4236/fns.2013.48A009

[19] Hossain, M.N., Akter, A., Humayan, S., Mohanto, L.C., Begum, S. and Ahmed, M.M. (2020) Edible Growth Medium: A New Window for Probiotic Research. Advances in Microbiology, 10, 39-51. https://doi.org/10.4236/aim.2020.102004 